\title{
Clinical utility gene card for: Nemaline myopathy
}

\author{
Kristen J Nowak ${ }^{1,2,5}$, Mark R Davis ${ }^{3,5}$, Carina Wallgren-Pettersson ${ }^{4}$, Phillipa J Lamont ${ }^{3}$ and Nigel G Laing ${ }^{\star, 1,2}$ \\ European Journal of Human Genetics (2012) 20, doi:10.1038/ejhg.2012.70; published online 18 April 2012
}

\section{DISEASE CHARACTERISTICS}

1.1 Name of the disease (synonyms)

Nemaline myopathy (NEM1 - NEM7)

Includes nemaline myopathy with excess thin filaments/actin aggregates; nemaline myopathy with cores; nemaline myopathy with intranuclear rods; and Amish nemaline myopathy.

\subsection{OMIM\# of the disease}

NEM1 - 609284; NEM2 - 256030; NEM3 - 161800; NEM4 - 609285;

NEM5 - 605355; NEM6 - 609273; NEM7 - 610687.

1.3 Name of the analysed genes or DNA/chromosome segments Slow muscle $\alpha$-tropomyosin (TPM3) - NEM1.

Nebulin (NEB) - NEM2.

Skeletal muscle $\alpha$-actin (ACTA1) - NEM3.

$\beta$-tropomyosin (TPM2) - NEM4.

Slow muscle troponin-T (TNNT1) - NEM5.

Kelch-repeat and BTB (POZ) Domain containing 13 (KBTBD13) NEM6.

Skeletal muscle cofilin (CFL2) - NEM7.

1.4 OMIM\# of the gene(s)

TPM3 $={ }^{\star} 191030 ; \quad N E B={ }^{\star} 161650 ; \quad$ ACTA $1={ }^{\star} 102610 ; \quad T P M 2=$

${ }^{\star} 190990 ;$ TNNT1 $={ }^{\star} 191041 ;$ KBTBD13 $={ }^{\star} 613727 ;$ CFL $2={ }^{\star} 601443$.

\subsection{Mutational spectrum}

TPM3

Mainly dominant, missense mutations, ${ }^{1,2}$ however some recessive mutations have been described. ${ }^{3,4} \mathrm{~A} 1 \mathrm{bp}$ recessive deletion occurs as a founder mutation in the Turkish population. ${ }^{5}$

\section{$N E B$}

All the over 140 mutations identified to date are recessive and the patients usually are compound heterozygous. The majority of the mutations are either frameshift or nonsense mutations, but also missense mutations, and point mutations and deletions affecting splice sites are known. ${ }^{6,7}$ An in-frame deletion of exon 55 is present in the Ashkenazi Jewish population at a carrier frequency of approximately 1 in $108 .^{8}$

\section{ACTA1}

Over 200 different mutations identified, with the majority causing nemaline myopathy, and nemaline myopathy with other features (for example, cores, actin aggregates, intranuclear rods). ${ }^{9}$ Of these, most mutations are dominant, missense, and have arisen de novo. ${ }^{9}$ About $10 \%$ are recessive mutations, and are genetic or functional null mutations. ${ }^{9}$ Dominant inheritance is less common, and only seen in families with a milder phenotype. ${ }^{9}$

\section{TPM2}

Two heterozygous, dominant missense mutations causing nemaline myopathy are known. ${ }^{10}$ Also a homozygous null mutation in a patient with nemaline and Escobar syndrome, ${ }^{11}$ and a dominant heterozygous mutation in a mother with nemaline myopathy and her daughter with cap myopathy. ${ }^{12}$

\section{TNNT1}

A recessive nonsense founder mutation is present in the Old Order Amish population. This produces characteristic progressive nemaline myopathy with tremors and contractures. ${ }^{13}$

\section{KBTBD13}

Three dominant missense mutations have been identified; however, not all mutation carriers in the families exhibited skeletal muscle weakness. ${ }^{14}$

CFL2

A single homozygous missense mutation has been identified in one family. 15

\subsection{Analytical methods}

The main analytical method is bi-directional Sanger sequencing of the entire coding region of the individual genes. If the family structure is amenable, linkage analysis for $N E B$ may be useful to pre-screen, owing to the large size of the gene. Next-generation sequencing will allow for simultaneous analysis of all genes in a patient.

\subsection{Analytical validation}

Mutations should be confirmed by resequencing using a fresh dilution of genomic DNA.

\subsection{Estimated frequency of the disease}

(incidence at birth ('birth prevalence') or population prevalence) For the most part, the frequency of the disease is unknown. In Finland, the birth prevalence has been estimated to be 0.02 per 1000 live births. ${ }^{16}$ Dominant mutations in ACTA1 and recessive mutations in $N E B$ are the most common causes of NEM. ${ }^{17,18}$

\footnotetext{
${ }^{1}$ Centre for Medical Research, The University of Western Australia, Nedlands, Western Australia, Australia; ${ }^{2}$ The Western Australian Institute for Medical Research, QEII Medical Centre, Nedlands, Western Australia, Australia; ${ }^{3}$ Neurogenetic Laboratory, Department of Anatomical Pathology, Royal Perth Hospital, Perth, Western Australia, Australia; ${ }^{4}$ The Folkhälsan Institute of Genetics and Department of Medical Genetics, Haartman Institute, University of Helsinki, Helsinki, Finland

${ }^{5}$ Equal first authors.

*Correspondence: Professor NG Laing, The Western Australian Institute for Medical Research, Ground Floor, B Block, QEll Medical Centre, Hovea Lane, Nedlands, Western Australia 6009, Australia. Tel: +61 89346 4611, Fax: +61 89346 1818, E-mail: Nigel.Laing@uwa.edu.au
} 
1.9 If applicable, prevalence in the ethnic group of investigated person

Recessive founder mutations are known to exist in particular genes in specific populations: TNNT1 in the Amish; ${ }^{13}$ NEB in the Ashkenazi Jewish; ${ }^{8}$ ACTA1 in the Pakistani community in England; and in French and Spanish Roma; ${ }^{9}$ and TPM3 in the Turkish population. ${ }^{5}$ These specific cases aside, no clear differences exist in prevalence rates between different ethnicities.

\subsection{Diagnostic setting}

\begin{tabular}{lll}
\hline & Yes & No \\
\hline A. (Differential) diagnostics & $\bigotimes$ & $\square$ \\
B. Predictive testing & $\boldsymbol{1}$ & $\square$ \\
C. Risk assessment in relatives & $\bigotimes$ & $\square$ \\
D. Prenatal & $\bigotimes$ & $\square$ \\
\hline
\end{tabular}

Comment: Requests for predictive testing are not common because of the early onset of the disease, but may be offered in families with childhood or late-onset forms of the disease.

\section{TEST CHARACTERISTICS}

\begin{tabular}{|c|c|c|c|c|}
\hline & \multicolumn{2}{|c|}{ Genotype or disease } & \multirow{2}{*}{$\begin{array}{l}\text { A: True positives } \\
\text { B: False positives }\end{array}$} & \multirow{2}{*}{$\begin{array}{l}\text { C: False negative } \\
\text { D: True negative }\end{array}$} \\
\hline & Present & Absent & & \\
\hline \multicolumn{5}{|l|}{ Test } \\
\hline \multirow[t]{2}{*}{ Positive } & A & B & Sensitivity: & $A /(A+C)$ \\
\hline & & & Specificity: & $D /(D+B)$ \\
\hline \multirow[t]{2}{*}{ Negative } & C & $\mathrm{D}$ & Positive predictive value: & $A /(A+B)$ \\
\hline & & & Negative predictive value: & $D /(C+D)$ \\
\hline
\end{tabular}

\subsection{Analytical sensitivity \\ (proportion of positive tests if the genotype is present) \\ $100 \%$}

\subsection{Analytical specificity \\ (proportion of negative tests if the genotype is not present) \\ $100 \%$}

\subsection{Clinical sensitivity}

(proportion of positive tests if the disease is present)

The clinical sensitivity can be dependent on variable factors such as age or family history. In such cases a general statement should be given, even if a quantification can only be made case by case.

The clinical sensitivity is dependent on factors such as age, inheritance pattern and additional clinical features. Because of the genetic heterogeneity, and particularly the difficulty of screening $N E B$, full screening of all known nemaline myopathy genes is rarely carried out. If full screening were to be undertaken, it may be estimated that approximately $75 \%$ of patients would have an identifiable mutation. ${ }^{6,9}$

\subsection{Clinical specificity}

(proportion of negative tests if the disease is not present)

The clinical specificity can be dependent on variable factors such as age or family history. In such cases, a general statement should be given, even if a quantification can only be made case by case.

Probably $100 \%$.
2.5 Positive clinical predictive value

(life-time risk to develop the disease if the test is positive)

Near $100 \%$. Potential incomplete penetrance has been suggested for certain ACTA1 variants. ${ }^{19}$

\subsection{Negative clinical predictive value}

(probability not to develop the disease if the test is negative) Assume an increased risk based on family history for a non-affected person. Allelic and locus heterogeneity may need to be considered.

Index case in that family had been tested:

Approximately 100\%.

Index case in that family had not been tested:

No predictive tests are usually performed in such cases.

\section{CLINICAL UTILITY}

3.1 (Differential) diagnosis: The tested person is clinically affected (To be answered if in 1.10 'A' was marked)

\subsubsection{Can a diagnosis be made other than through a genetic test?}

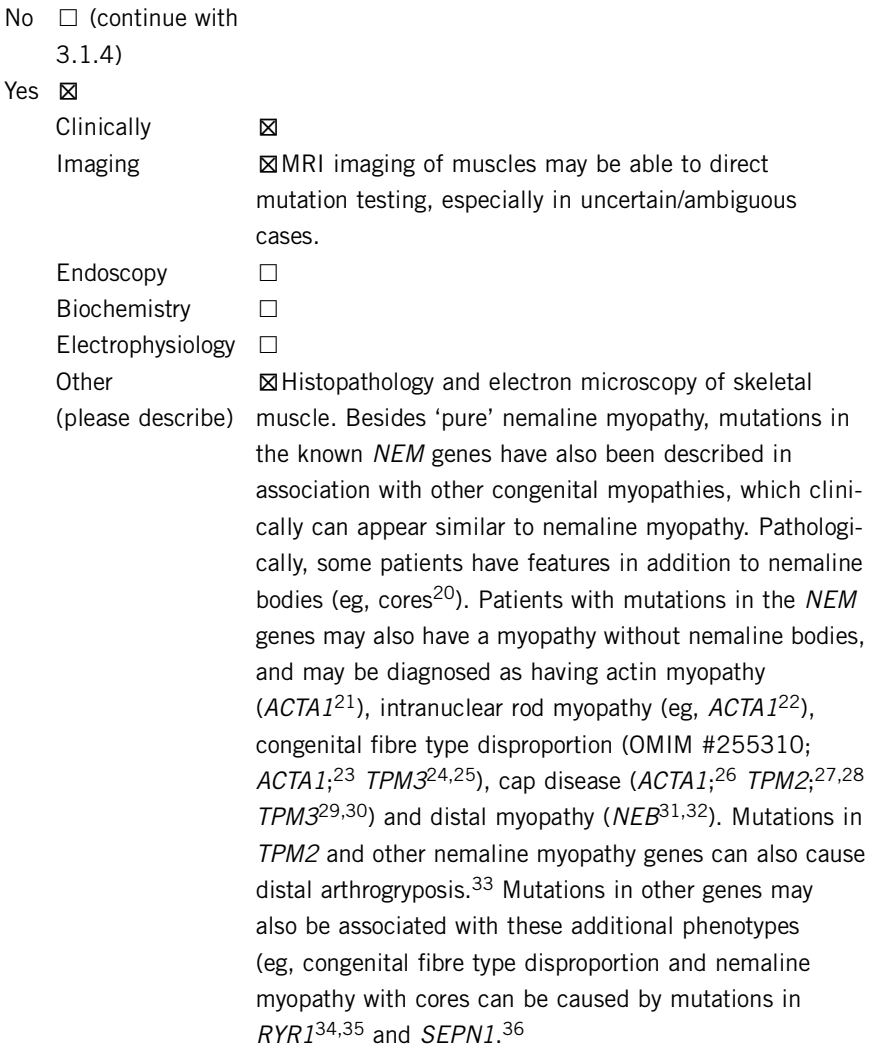

\subsubsection{Describe the burden of alternative diagnostic methods to the} patient

Nemaline myopathy requires both a clinical and, significantly, a histopathological/electron microscopic diagnosis. Therefore, a thorough assessment including a detailed evaluation of clinical and pathological features should be performed before genetic testing. As such, histopathology and electron microscopy are not diagnostic alternatives, rather prerequisites to genetic testing. Nevertheless, muscle biopsy is an invasive procedure, and appropriate histological and electron microscopic examination requires proximity to a specialised laboratory set up. 
3.1.3 How is the cost effectiveness of alternative diagnostic methods to be judged?

Not applicable.

\subsubsection{Will disease management be influenced by the result of a genetic test?}

\begin{tabular}{|c|c|}
\hline 凶 & \\
\hline $\begin{array}{l}\text { Therapy } \\
\text { (please describe) }\end{array}$ & $\begin{array}{l}\text { Presently, the treatment of patients is based on } \\
\text { symptom management, which would occur regardless } \\
\text { of the genetic diagnosis. However, an accurate } \\
\text { genetic diagnosis will undoubtedly be extremely } \\
\text { important for any gene- or mutation-dependent } \\
\text { therapies once they are developed. }\end{array}$ \\
\hline $\begin{array}{l}\text { Prognosis } \\
\text { (please describe) }\end{array}$ & $\begin{array}{l}\text { Congenital myopathies are usually considered } \\
\text { non-progressive; however, it is variable, as nemaline } \\
\text { myopathy can be severe (congenital presentation) } \\
\text { through to mild, }{ }^{37} \text { even with mutations in the same } \\
\text { gene. For example, most patients with ACTA1 mutations } \\
\text { die within their first year of life, but some patients } \\
\text { have a milder phenotype compatible with survival } \\
\text { into adulthood. }{ }^{9} \text { However, even severely affected } \\
\text { patients who can get through the first year of life } \\
\text { can do better subsequently. Patients with the } \\
\text { recessive TNNTI mutation die within } 2 \text { years } \\
\text { of birth. }\end{array}$ \\
\hline $\begin{array}{l}\text { Management (please } \\
\text { describe) }\end{array}$ & $\begin{array}{l}\text { Supportive-mechanical ventilation; night-time ventila- } \\
\text { tion; naso-gastric feeding; mobility aids; physio, occu- } \\
\text { pational and speech therapy. Genetic testing required } \\
\text { for verifying the diagnosis and determining the mode of } \\
\text { inheritance, which serves as a basis for genetic } \\
\text { counselling. }\end{array}$ \\
\hline
\end{tabular}

3.2 Predictive Setting: The tested person is clinically unaffected but carries an increased risk based on family history

(To be answered if in 1.10 'B' was marked)

Predictive testing is usually only applicable for the milder versions of nemaline myopathy, as most often the disease presents before, at, or shortly after birth.

\subsubsection{Will the result of a genetic test influence lifestyle and prevention?}

If the test result is positive (please describe):

A positive result may perhaps influence decisions in terms of lifestyle choices, for example, deciding which career to pursue (eg, an office job compared with a more physical occupation), whether to travel at a young age when mobility is not affected compared with later in life after the disease onsets, and whether to have a house on one level as opposed to over multiple stories (eg, the latter would involve climbing lots of stairs which might become problematic).

If the test result is negative (please describe):

A negative result may influence lifestyle choices in the opposite directions to those indicated above.

3.2.2 Which options in view of lifestyle and prevention does a person at-risk have if no genetic test has been done (please describe)? Not applicable.

3.3 Genetic risk assessment in family members of a diseased person (To be answered if in 1.10 ' $\mathrm{C}$ ' was marked)
3.3.1 Does the result of a genetic test resolve the genetic situation in that family?

Yes, if a mutation/s is identified.

3.3.2 Can a genetic test in the index patient save genetic or other tests in family members?

Yes.

3.3.3 Does a positive genetic test result in the index patient enable a predictive test in a family member?

Yes, but owing to very early disease onset in most cases, it is infrequently encountered.

\subsection{Prenatal diagnosis}

(To be answered if in 1.10 ' $\mathrm{D}$ ' was marked)

\subsubsection{Does a positive genetic test result in the index patient enable a prenatal diagnosis?}

Yes. In cases where dominant de novo mutations have been identified in an affected child, genetic counselling may be difficult, as the recurrence risk is between 0 and $50 \%$, and there is currently insufficient empirical data to indicate the risk. However, prenatal genetic testing of an at-risk pregnancy is accurate.

\section{IF APPLICABLE, FURTHER CONSEQUENCES OF TESTING}

Please assume that the result of a genetic test has no immediate medical consequences. Is there any evidence that a genetic test is nevertheless useful for the patient or his/her relatives? (Please describe)

Yes, particularly if a mutation/s are identified. An accurate genetic diagnosis often ends a lengthy diagnostic odyssey for the patient and their family, removing the psychological affects of an absent disease cause, and can sometimes influence possible prognosis. An accurate genetic diagnosis can crucially indicate mode of inheritance and underpins genetic counselling, including options such as prenatal and pre-implantation testing.

\section{CONFLICT OF INTEREST}

The authors declare no conflict of interest.

\section{ACKNOWLEDGEMENTS}

This work was supported by EuroGentest2 (Unit 2: 'Genetic testing as part of health care'), a Coordination Action under FP7 (grant agreement number 261469), the European Society of Human Genetics, an Australian National Health and Medical Research Council (NH\&MRC) Fellowship APP1002147, and an Australian Research Council (ARC) Future Fellowship FT100100734.

1 Laing NG, Wilton SD, Akkari PA et al: A mutation in the alpha tropomyosin gene TPM3 associated with autosomal dominant nemaline myopathy. Nat Genet 1995; 9: 75-79.

2 Kiphuth IC, Krause S, Huttner HB, Dekomien G, Struffert T, Schroder R: Autosomal dominant nemaline myopathy caused by a novel alpha-tropomyosin 3 mutation J Neurol 2010; 257: 658-660.

3 Tan P, Briner J, Boltshauser E et al: Homozygosity for a nonsense mutation in the alpha-tropomyosin slow gene TPM3 in a patient with severe infantile nemaline myopathy. Neuromuscul Disord 1999; 9: 573-579.

4 Wattanasirichaigoon D, Swoboda KJ, Takada F et al: Mutations of the slow muscle alpha-tropomyosin gene, TPM3, are a rare cause of nemaline myopathy. Neurology 2002; 59: 613-617.

5 Lehtokari VL, Pelin K, Donner $\mathrm{K}$ et al: Identification of a founder mutation in TPM3 in nemaline myopathy patients of Turkish origin. Eur J Hum Genet 2008; 16: 1055-1061.

6 Pelin K, Hilpela $\mathrm{P}$, Donner $\mathrm{K}$ et al: Mutations in the nebulin gene associated with autosomal recessive nemaline myopathy. Proc Natl Acad Sci USA 1999; 96 : 2305-2310 
7 Lehtokari VL, Pelin K, Sandbacka M et al: Identification of 45 novel mutations in the nebulin gene associated with autosomal recessive nemaline myopathy. Hum Mutat 2006; 27: 946-956.

8 Anderson SL, Ekstein J, Donnelly MC et al: Nemaline myopathy in the Ashkenazi Jewish population is caused by a deletion in the nebulin gene. Hum Genet 2004; 115: 185-190.

9 Laing NG, Dye DE, Wallgren-Pettersson C et al: Mutations and polymorphisms of the skeletal muscle alpha-actin gene (ACTA1). Hum Mutat 2009; 30: 1267-1277.

10 Donner K, Ollikainen M, Ridanpaa M et al: Mutations in the beta-tropomyosin (TPM2) gene-a rare cause of nemaline myopathy. Neuromuscul Disord 2002; 12: 151-158.

11 Monnier N, Lunardi J, Marty I et al: Absence of beta-tropomyosin is a new cause of Escobar syndrome associated with nemaline myopathy. Neuromuscul Disord 2009; 19: 118-123.

12 Tajsharghi H, Ohlsson M, Lindberg C, Oldfors A: Congenital myopathy with nemaline rods and cap structures caused by a mutation in the beta-tropomyosin gene (TPM2). Arch Neurol 2007; 64: 1334-1338.

13 Johnston JJ, Kelley RI, Crawford TO et al: A novel nemaline myopathy in the Amish caused by a mutation in troponin T1. Am J Hum Genet 2000; 67: 814-821.

14 Sambuughin N, Yau KS, Olive M et al: Dominant mutations in KBTBD13, a member of the BTB/Kelch family, cause nemaline myopathy with cores. Am J Hum Genet, 87: 842-847.

15 Agrawal PB, Greenleaf RS, Tomczak KK et al: Nemaline myopathy with minicores caused by mutation of the CFL2 gene encoding the skeletal muscle actin-binding protein, cofilin-2. Am J Hum Genet 2007; 80: 162-167.

16 Wallgren-Pettersson C: Congenital Nemaline Myopathy: A Longitudinal Study. University of Helsinki, Helsinki, 1990.

17 Wallgren-Pettersson C, Pelin K, Hilpela P et al: Clinical and genetic heterogeneity in autosomal recessive nemaline myopathy. Neuromuscul Disord 1999; 9: 564-572.

18 Wallgren-Pettersson C, Laing NG: Report of the 83rd ENMC International Workshop: 4th Workshop on Nemaline Myopathy, 22-24 September 2000, Naarden, The Netherlands. Neuromuscul Disord 2001; 11: 589-595.

19 Agrawal PB, Strickland CD, Midgett $C$ et al: Heterogeneity of nemaline myopathy cases with skeletal muscle alpha-actin gene mutations. Ann Neurol 2004; 56: 86-96.

20 Jungbluth $\mathrm{H}$, Sewry CA, Brown SC et al: Mild phenotype of nemaline myopathy with sleep hypoventilation due to a mutation in the skeletal muscle alpha-actin (ACTA1) gene. Neuromuscul Disord 2001; 11: 35-40.

21 Nowak KJ, Wattanasirichaigoon D, Goebel HH et al: Mutations in the skeletal muscle alpha-actin gene in patients with actin myopathy and nemaline myopathy. Nat Genet 1999; 23: 208-212.

22 Hutchinson DO, Charlton A, Laing NG, Ilkovski B, North KN: Autosomal dominant nemaline myopathy with intranuclear rods due to mutation of the skeletal muscle
ACTA1 gene: clinical and pathological variability within a kindred. Neuromuscul Disord 2006; 16: 113-121.

23 Laing NG, Clarke NF, Dye DE et al: Actin mutations are one cause of congenital fibre type disproportion. Ann Neurol 2004; 56: 689-694.

24 Clarke NF, Kolski H, Dye DE et al: Mutations in TPM3 are a common cause of congenital fiber type disproportion. Ann Neurol 2008; 63: 329-337.

25 Lawlor MW, Dechene ET, Roumm E, Geggel AS, Moghadaszadeh B, Beggs AH: Mutations of tropomyosin 3 (TPM3) are common and associated with type 1 myofiber hypotrophy in congenital fiber type disproportion. Hum Mutat 2010; 31: 176-183.

26 Hung RM, Yoon G, Hawkins CE, Halliday W, Biggar D, Vajsar J: Cap myopathy caused by a mutation of the skeletal alpha-actin gene. ACTA1. Neuromuscul Disord 2010; 20: 238-240.

27 Lehtokari VL, Ceuterick-de Groote C, de Jonghe P et al: Cap disease caused by heterozygous deletion of the beta-tropomyosin gene. TPM2. Neuromuscul Disord 2007; 17: 433-442.

28 Clarke NF, Domazetovska A, Waddell L, Kornberg A, McLean C, North KN: Cap disease due to mutation of the beta-tropomyosin gene (TPM2). Neuromuscul Disord 2009; 19 . 348-351.

29 Ohlsson M, Fidzianska A, Tajsharghi H, Oldfors A: TPM3 mutation in one of the original cases of cap disease. Neurology 2009; 72: 1961-1963.

30 De Paula AM, Franques J, Fernandez C et al: A TPM3 mutation causing cap myopathy. Neuromuscul Disord 2009; 19: 685-688.

31 Wallgren-Pettersson C, Lehtokari VL, Kalimo $\mathrm{H}$ et al: Distal myopathy caused by homozygous missense mutations in the nebulin gene. Brain 2007; 130: 1465-1476.

32 Lehtokari VL, Pelin K, Herczegfalvi A et al: Nemaline myopathy caused by mutations in the nebulin gene may present as a distal myopathy. Neuromuscul Disord 2011; 21: $556-562$.

33 Sung SS, Brassington AM, Grannatt $\mathrm{K}$ et al: Mutations in genes encoding fast-twitch contractile proteins cause distal arthrogryposis syndromes. Am J Hum Genet 2003; 72: 681-690.

34 Scacheri PC, Hoffman EP, Fratkin JD et al: A novel ryanodine receptor gene mutation causing both cores and rods in congenital myopathy. Neurology 2000; 55: 1689-1696.

35 Clarke NF, Waddell LB, Cooper ST et al: Recessive mutations in RYR1 are a common cause of congenital fiber type disproportion. Hum Mutat 2010; 31: E1544-E1550.

36 Clarke NF, Kidson W, Quijano-Roy S et al: SEPN1: associated with congenital fiber-type disproportion and insulin resistance. Ann Neurol 2006; 59: 546-552.

37 Wallgren-Pettersson C, Laing NG: Report of the 70th ENMC International Workshop: nemaline myopathy, 11-13 June 1999, Naarden, The Netherlands. Neuromuscul Disord 2000; 10: 299-306. 